\title{
High and dry or sunk and dunked: lessons for tallgrass prairies from quaking bogs
}

\author{
Ann B. Swengel $\cdot$ Scott R. Swengel
}

Received: 4 March 2010/Accepted: 31 August 2010/Published online: 14 September 2010

(C) The Author(s) 2010. This article is published with open access at Springerlink.com

\begin{abstract}
Northern Wisconsin bogs provide a natural experiment on butterfly population occurrence in a naturally highly fragmented vegetation type, which may provide insight on conserving butterflies in anthropogenically fragmented and degraded landscapes. We surveyed butterflies in bogs (about as unaffected by humans as possible, but naturally occurring over $<1 \%$ of northern Wisconsin) primarily during 2002-2009, with additional observations from 1986 to 2001. Different bog types had different bogspecialist butterfly faunas, but bog butterfly abundance also differed in similar vegetations among subregions. Some small isolated bogs held very high densities of specialist butterflies. Summer but not spring specialists frequented adjacent lowland roadsides and utilized a variety of nonnative as well as native nectar sources. Paleo-entomology indicates that insects don't evolve out of trouble; instead they move out of trouble. Given the low dispersal apparent today for species restricted to bogs, "move" might be better understood as "hunkering" within their vegetation as it expands and shrinks and moves around the landscape. Although bogs appeared to have more intact specialist butterfly faunas than tallgrass prairies ( $99.9 \%$ destroyed by human activities), bog butterflies do not live in average sites even in a relatively natural landscape. Just as bog butterflies are "sunk and dunked" in isolation, specialist butterflies elsewhere may have been left "high and dry" naturally, or are now due to human activities. Numerous studies have demonstrated that presence and abundance of specialist butterflies increase with increasing size and connectedness of habitat patches. But with long-term consistent vegetation, populations with high abundances in small isolated
\end{abstract}

A. B. Swengel $(\bowtie) \cdot$ S. R. Swengel

909 Birch St., Baraboo, WI 53913, USA

e-mail: swengel@naba.org sites and with low numbers thinly occurring in large sites can be secure, as shown by bog butterflies.

Keywords Bog $\cdot$ Specialist butterfly $\cdot$ Population persistence · Dispersal · Co-evolution · Stasis · Habitat quality - Landscape configuration · Habitat fragmentation · Vegetative consistency

\section{Introduction}

A major threat to biodiversity is human-caused habitat loss and fragmentation, with degradation of extant patches by edge effects and disruption of ecological processes (Brown 1997; van Swaay et al. 2006; Forister et al. 2010). Butterfly populations fare more poorly in isolated or small sites, with nearer and larger sites more likely to remain occupied or become re-colonized (Bulman et al. 2007; Hanski and Pöyry 2007; Dover and Settele 2009). Both habitat quality and landscape configuration are important for maintaining butterfly populations (Dennis and Eales 1997; Thomas et al. 2001; Hanski and Pöyry 2007; Dennis 2010), and both are under more threat in a human-degraded, fragmented landscape. As a result, much research in conservation biology concerns how to counteract the effects of habitat loss, degradation, and fragmentation on vulnerable species (e.g., Mattoni et al. 2001; Thomas et al. 2001; Dennis and Hardy 2007; Swengel and Swengel 2007; Spencer and Collins 2008; Dennis 2010).

In the midwestern USA, tallgrass prairie (predominately herbaceous flora) and oak savanna (trees and brush mixed in with herbaceous patches) have been about 99\% destroyed primarily by conversion to agriculture (Curtis 1959; Nuzzo 1986; Samson and Knopf 1994). Pine barrens (a savanna on very sandy soil) have also declined but not to 
the same degree (Curtis 1959; Riegler 1995). Fragmentation and degradation greatly affect remaining examples of these vegetations and their associated butterflies (Samson and Knopf 1994; Riegler 1995; Swengel and Swengel 1999a, 2001).

In temperate areas of North America and Europe, bog (peatland) vegetation is also rare, being naturally isolated and forming a low proportion of the natural landscape. Although often viewed as a long-lived successional stage between open water and forest in glaciated landscapes, peatlands can get reset to an earlier successional stage (Curtis 1959). Since bogs are well known for their relatively stable vegetations and insect faunas over the long term, they can also be viewed as a climax community (Spitzer et al. 1999; Spitzer and Danks 2006; Whitehouse 2006; Whitehouse et al. 2008). While often considered relatively uniform floristically both within and among sites, bogs actually contain many microhabitats (Väisänen 1992; Spitzer and Danks 2006; Turlure et al. 2009, 2010). In Wisconsin, bogs occur primarily in central and northern areas (Curtis 1959). Prior to European settlement, peatlands occurred in $<1 \%$ of the Wisconsin landscape (even counting only the northern third of the state), and most of that vegetation is still extant, with only 9\% loss (Hoffman 2002), more lost in central than northern Wisconsin. Much of what is left, especially in northern Wisconsin, is relatively undegraded. Primary human impacts are roads and ditches; adjacent lands are more affected by timber harvesting, agriculture, and urbanization (pers. obs.). Conversion to cranberry agriculture and peat harvesting has occurred more in central Wisconsin bogs (Curtis 1959). By contrast, in Europe bog vegetation is much destroyed and degraded by human activities, along with the associated butterfly species of high conservation concern (Vandewoestijne and Baguette 2004; Schtickzelle et al. 2006; Spencer and Collins 2008; Turlure et al. 2009). The four bog-related vegetation types ranked highest in proportion of threatened butterfly species of their typical faunas (van Swaay et al. 2006).

In addition to observations by a few other lepidopterists, Nekola (1998) conducted a systematic survey of northern Wisconsin peatlands and their associated butterflies in 1996. He described three peatland types: muskeg (black spruce-cottongrass-wiregrass savanna similar in elevation to surrounding uplands), kettlehole (sphagnum-leatherleaf mats, often floating on lakes or sunk in depressions much lower than the surrounding landscape), and coastal peatland (tamarack-sedge mats with ridges of muskeg-like vegetation in estuaries along the Lake Superior coast). Many aspects of the flora are similar among these three types (Nekola and Kraft 2002), echoing Curtis's (1959) description of remarkably uniform bog structure and composition throughout the circumboreal region. Nekola
(1998) nevertheless found significant differences in bogobligate butterfly occurrence among these three bog types, and noted variation in flora amongst sites, especially kettleholes.

We have recorded butterflies in Wisconsin bogs since 1986. In this paper, we analyze these results to expand and extend Nekola's study in order to describe patterns of bog butterfly occurrence and abundance. We examine butterfly occurrence and abundance in bogs in relation to bog type, size, and isolation, and in adjacent lowland roadside ditches and nearby upland roadsides. This provides evidence on the relative importance to specialist butterfly population persistence of dispersal tendency, habitat quality, and landscape configuration. During the same period, we conducted surveys of butterflies in prairies in seven midwestern states (Swengel 1996; Swengel and Swengel 1999b, Swengel and Swengel 2007) and Wisconsin pine barrens (Swengel 1998; Swengel and Swengel 2005, 2007). Based on this field work and others' studies, we contrast the occurrence of specialist butterflies between vegetations altered and fragmented by humans (prairie, barrens) and naturally fragmented ones (bogs). These results should be useful for application to conservation of bog butterflies where they are vulnerable, and vulnerable butterflies in other fragmented vegetations.

\section{Methods}

\section{Study regions}

The primary study region contains 73 bog sites scattered across an area $367 \mathrm{~km}$ east-west by $169 \mathrm{~km}$ north-south $\left(45.33-46.86^{\circ} \mathrm{N}, 88.21-92.56^{\circ} \mathrm{W}\right)$ in twelve contiguous counties spanning the entire breadth of northern Wisconsin. At 20 of these sites, we also surveyed the lowland (wetland) roadside ditch through or adjacent to the bog, and at five sites, we surveyed a more upland roadside corridor 20-350 m from the bog. In three large muskeg complexes, we counted surveys in each separate area as a separate site. In central Wisconsin, the three bogs in two contiguous counties (Jackson, Wood) are in an area $29 \mathrm{~km}$ east-west by $4 \mathrm{~km}$ north-south $\left(44.31-44.34^{\circ} \mathrm{N}, 90.19-90.56^{\circ} \mathrm{W}\right)$, which is $169 \mathrm{~km}$ south of the nearest study site in the northern study region. Nekola's (1998) study region comprises sites in and adjacent to the Lake Superior drainage basin in four contiguous counties (Ashland, Bayfield, Douglas, Iron) bordering the south lakeshore. This area is the north part of the west half of our northern study region. All our sites in those counties fall within his study region.

Within each study region, we biased toward high-quality examples of bog vegetation that were open to public visitation and efficient to gain access to and travel between due 
to clustering of sites and/or efficient routing among sites, including proximity to other kinds of sites of interest for other species. Nonetheless, peatlands often present difficulties of access both to them and across them, which reduces efficiency and amount of transect distance surveyed in a day. Roadside survey areas were selected because we noticed bog butterflies using them, they were en route to or from a bog survey route, or they appeared potentially of interest for either bog or other butterfly species.

\section{Surveys}

On 114 informal visits during 1986-2001 in both study regions (widely in the northern one), we recorded number of individuals by species per site, but did not standardize a route or record weather and effort (time and distance spent surveying). We began formal transect surveys in bogs in 1990, with most conducted during 2002-2009 (Table 1). In those last 8 years, we surveyed in a rotation through the western, central, and eastern sections of the northern study region, trying to cover one section per weekend, or more if a section was missed the previous weekend and/or if time allowed. But we missed an occasional weekend per year due to weather or another commitment. Surveys occurred between 23 April and 12 September, usually early/mid May through early/mid August in most years. We also continued to record bog specialists informally observed in uplands and roadsides as we accessed bogs for formal surveys.

Our peatland transect surveys were like those in prairie and barrens (similar to Pollard 1977 and as described in Swengel 1996, 1998; Swengel and Swengel 1997). We walked along a similar route per visit to a prairie, barrens, or bog at a slow pace (about $2 \mathrm{~km} / \mathrm{h}$ ) on parallel routes 5-10 $\mathrm{m}$ apart. We counted all adult butterflies observed

Table $1 N$ surveys of units and survey effort $(\mathrm{km}, \mathrm{h})$ in central and northern Wisconsin at 76 bog sites, 20 lowland roadsides, and 5 upland roadsides, from 23 April to 12 September

\begin{tabular}{lllll}
\hline & $N$ & Years & Km & Hours \\
\hline 1987-2001 & & & & \\
All sites & 50 & $1987-2001$ & 44.0 & 25.8 \\
Bog & 27 & $1990-2001$ & 21.5 & 13.1 \\
Lowland & 5 & $1999-2001$ & 3.1 & 2.1 \\
Upland & 18 & $1987-1996,1998-2001$ & 19.5 & 10.7 \\
2002-2009 & & & & \\
All sites & 1,973 & $2002-2009$ & 921.9 & 377.2 \\
Bog & 1,699 & $2002-2009$ & 806.5 & 321.3 \\
Lowland & 223 & $2002-2009$ & 80.5 & 42.5 \\
Upland & 51 & $2002-2009$ & 34.9 & 13.5 \\
\hline
\end{tabular}

ahead and to the sides, to the limit at which an individual could be identified, possibly with the aid of binoculars after detection, and tracked. A new sampling unit was designated whenever the vegetation along the route varied by management (type and/or years since last treatment), type (wet, mesic, dry), quality based on type of brush and diversity and abundance of native and exotic flora (undegraded, semi-degraded, highly degraded), and/or estimated macrosite canopy (grassland or open bog $<10 \%$, open savanna $10-24 \%$, closed savanna $25-49 \%$, forest opening $50-75 \%)$. Routes crossed rather than followed ecotones and management boundaries to reduce edge effects, and were designed to minimize number of unit changes while covering representative areas of the site. Temperature (starting, ending, low, high), wind speed, percent cloud cover, percent time sun was shining, route distance, and time spent surveying were recorded for each unit. Data from each unit were kept separate. Surveys occurred during a wide range of times of day and weather, occasionally in intermittent light drizzle so long as butterfly activity was apparent, but not in continuous rain. All butterfly species found were counted, but survey times and locations were selected to study butterflies specialized to that vegetation.

In prairie and barrens, we categorized the species by habitat niche breadth (Swengel 1996, 1998): (1) specialist (restricted or nearly so to herbaceous flora in prairie and/or savanna; sensitive to vegetative quality); (2) grassland species (widely inhabiting both native and degraded herbaceous flora); (3) generalist (inhabiting grassland and other vegetation types); and (4) immigrant (occurring in the study region during the growing season but unlikely to overwinter). In bogs, we used an analogous categorization applicable to this study region only, and these categories correspond approximately to those (in parentheses) described by Spitzer and Danks (2006) (Table 2): (1) bog specialist (tyrphobiontic) - restricted or nearly so to peatlands; (2) bog affiliate (tyrphophilic) — breeding in bogs as well as other vegetations (limited to species of north temperate or boreal affinity); (3) generalist (tyrphoneutral) year-round resident primarily using vegetation other than bogs (if the species also breeds in bogs, its range includes non-montane areas well south of Wisconsin); and (4) immigrant (tyrphoxenous) - not a year-round resident of the region and unlikely to breed in bogs. In Wisconsin, the bog specialists are all at the southern end of their eastern North American range, with their known range not extending into the state immediately south of Wisconsin, but further east $L$. epixanthe and $L$. dorcas may occur in areas more southerly than Wisconsin (Opler 1992; Glassberg 1999; Nielsen 1999).

Especially in bogs, we surveyed in a wider range of weather conditions than prescribed in Pollard (1977) and Wikström et al. (2009). We experienced severe constraints 
Table 2 Total individuals of each specialist and affiliate species in bogs, lowland roadsides, and upland roadsides during 1987-2009 on formal surveys (informal observations in lowland and upland roadsides in parentheses)

\begin{tabular}{|c|c|c|c|c|c|c|}
\hline \multicolumn{3}{|l|}{ Species } & Bog & Lowl & Upl & Notes \\
\hline \multicolumn{7}{|c|}{ Bog specialists } \\
\hline $\mathrm{L}$ & MCK & Bog copper Lycaena epixanthe & 3,986 & 674 & 2 & 23 Jun-15 Aug \\
\hline $\mathrm{N}$ & MCK & Bog fritillary Boloria eunomia & 1,084 & 0 & $1(1)$ & 9 Jun-14 Jul \\
\hline $\mathrm{N}$ & MCK & Jutta arctic Oeneis jutta & 962 & 1 & 0 & 12 May-10 Jul \\
\hline $\mathrm{N}$ & MCK & Freija fritillary Boloria freija & 722 & 0 & 0 & 7 May-15 Jun \\
\hline $\mathrm{N}$ & M & Frigga fritillary Boloria frigga & 264 & $0(1)$ & 0 & 19 May-20 Jun \\
\hline $\mathrm{N}$ & M & Purplish fritillary Boloria montinus & 192 & 1,093 & 0 & 27 Jul-23 Aug \\
\hline $\mathrm{L}$ & $\mathrm{MC}$ & Dorcas copper Lycaena dorcas & 163 & 379 & 0 & 26 Jun-15 Aug \\
\hline $\mathrm{N}$ & M & Red-disked alpine Erebia discoidalis & 128 & 1 & 0 & 10 May-14 Jun \\
\hline \multicolumn{7}{|c|}{ Bog affiliates } \\
\hline $\mathrm{L}$ & \multicolumn{2}{|c|}{ Brown elfin Callophrys augustinus } & 4,304 & 6 & 0 & \\
\hline $\mathrm{N}$ & \multicolumn{2}{|c|}{ Inornate ringlet Coenonympha tullia } & 607 & 167 & 10 & \\
\hline $\mathrm{Pi}$ & \multicolumn{2}{|c|}{ Pink-edged sulphur Colias interior } & 302 & 229 & 12 & \\
\hline $\mathrm{N}$ & \multicolumn{2}{|c|}{ Eyed brown Satyrodes eurydice } & 245 & 251 & 81 & \\
\hline $\mathrm{H}$ & \multicolumn{2}{|c|}{ Dreamy duskywing Erynnis icelus } & 168 & 7 & 2 & \\
\hline $\mathrm{N}$ & \multicolumn{2}{|c|}{ Silver-bordered fritillary Boloria selene } & 123 & 95 & 19 & \\
\hline $\mathrm{N}$ & \multicolumn{2}{|c|}{ Atlantis fritillary Speyeria atlantis } & 46 & 299 & 134 & \\
\hline $\mathrm{N}$ & \multicolumn{2}{|c|}{ Harris' checkerspot Chlosyne harrisii } & 32 & 29 & 0 & \\
\hline $\mathrm{N}$ & \multicolumn{2}{|c|}{ Green comma Polygonia faunus } & 1 & 0 & 0 & \\
\hline
\end{tabular}

Family is abbreviated as $P$ Papilionidae, $P i$ Pieridae, $L$ Lycaenidae, $N$ Nymphalidae, $H$ Hesperiidae. Abbreviations for site types each specialist was recorded in: $M$ muskeg, $C$ coastal peatland, $K$ kettlehole. Butterfly names follow Cassie et al. (2001)

on obtaining suitable weather especially in spring. The bog-specialist species varied greatly in detectability relative to weather. For example, temperatures of $13-14^{\circ} \mathrm{C}$ (if sunny) were excellent for surveying Boloria freija, which is active but not too active then, while Erebia discoidalis is most effectively surveyed at mid-day in the warmest sunniest conditions possible (at least $16^{\circ} \mathrm{C}$ but preferably $18-19^{\circ} \mathrm{C}$ or warmer as described in Swengel 2009). Both these species have similar spring flight periods (Table 2). The tan and brown color of the vegetation in spring results in warmer microclimates in and between peat hummocks relative to overall air temperature, which may facilitate butterfly activity in cooler conditions than usually recommended for butterfly surveying. The negative effect of subpar weather on butterfly detection in our survey results is not a systematic bias, as we did not (and could not) bias which sites were surveyed in better weather, so that this factor confounds statistical power, but doesn't systematically misdirect it.

\section{Analyses}

As in Nekola and Kraft (2002), we identified the flight period per species by the first and last date per year we detected it, separately for the two study regions, and in northern Wisconsin, separately for coastal peatlands, which were much later in phenology than the other sites (Swengel 2009). We also determined flight period spans separately for different areas of inland northern Wisconsin when phenological differences were evident for a particular species (e.g., L. epixanthe in Swengel 2009). In the case of single outlier individuals observed, we did not consider it flight period at sites where not seen. Our population index is the peak survey count per site per brood, standardized to survey time, to create an observation rate (relative abundance) per hour per unit survey. Since Oeneis jutta may have a two-year life cycle, with one cohort larger than the other (Opler and Krizek 1984), we tested for a skewed distribution by even and odd years. Although significantly different (Table 3), even-year cohorts were $73 \%$ the abundance of odd-year cohorts, well within the range of typical variation from annual fluctuation reported for specialist butterflies (Pollard and Yates 1993; Swengel and Swengel 2007). For this reason, we pooled all available years for this species' analyses.

Analysis was done with ABstat 7.20 software (1994 Anderson-Bell Corp., Parker, Colorado). Statistical significance was set at two-tailed $P<0.05$. Since significant results occurred at a frequency well above that expected due to spurious Type I statistical error, the critical $P$ value was not lowered further, as more Type II errors (biologically meaningful patterns lacking statistical significance) 
Table 3 Distribution of Oeneis jutta individuals on peak count per year at sites ever reporting the species, by even and odd years during 2002-2009, significantly skewed from expected based on survey effort (h) in each group of years (chi square goodness of fit test $P=0.0000$ )

\begin{tabular}{llllr}
\hline & Observed individuals & Survey time & Expected individuals & Observation rate (h) \\
\hline Odd years & 503 & $47.19(54.6 \%)$ & 442 & 10.7 \\
Even years & 307 & $39.26(45.4 \%)$ & 368 & 7.8 \\
Total & 810 & 86.45 & 810 & \\
\hline
\end{tabular}

would be created than Type I errors eliminated. All correlations were done with the Spearman rank correlation. To test for significant skewing compared to distribution proportional to survey effort (h), we used the Chi Square Goodness of Fit test, and to test for significant differences in relative abundance among sites, we used the MannWhitney $U$ test. All statistical tests in this study are nonparametric, which do not require any assumptions about how the data are distributed (e.g., normality).

\section{Results}

We recorded the same specialists in muskegs as in Nekola's (1998) study (Table 2). The few additional species we recorded in kettleholes and coastal peatlands within Nekola's (1998) study region were infrequently encountered in only one or two sites per bog type (in coastal peatlands, one $B$. freija at one site, five $O$. jutta at one site, and seven $L$. dorcas at two sites; in kettleholes, three $B$. freija at one site).

In analysis of the peak surveys per year of the four most frequently recorded specialists (Figs. 1, 2; Appendix 1), significant differences in abundances occurred among bog types. Significantly highest abundances of L. epixanthe and $B$. eunomia were in kettleholes and coastal peatlands,

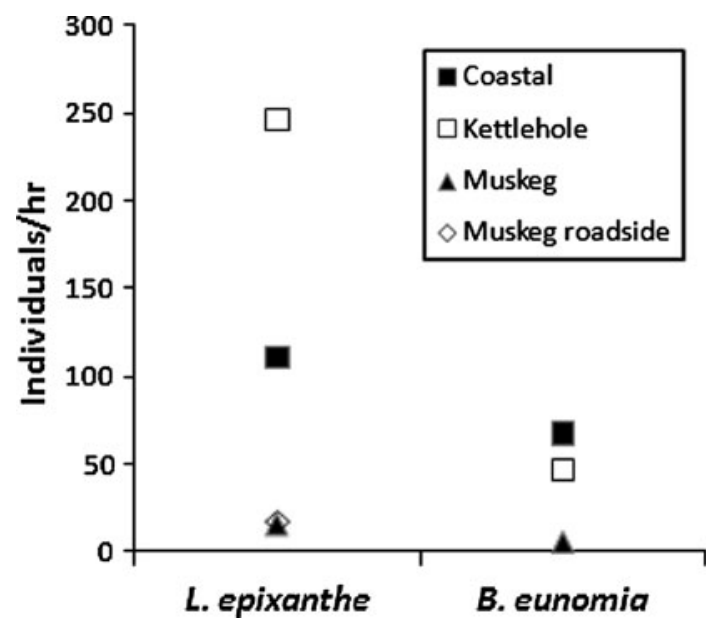

Fig. 1 Grand means of average relative abundance (peak individuals/ hr per site per year) of L. epixanthe and B. eunomia in sets of sites grouped by bog type, as in "Appendix 1"

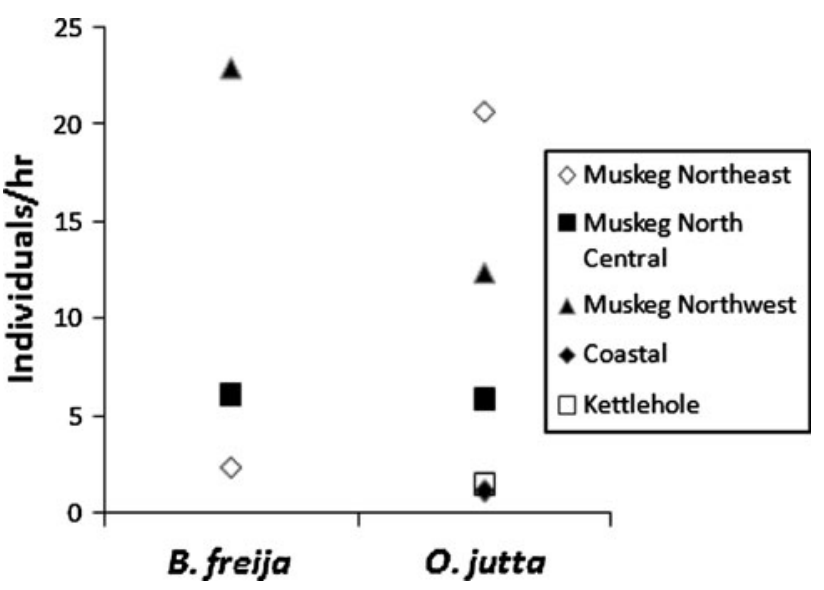

Fig. 2 Grand means of average relative abundance (peak individuals/ hr per site per year) of $B$. freija and $O$. jutta in sets of sites grouped by bog type, and for muskeg, by subregion, as in "Appendix 1" (coastal peatlands and kettleholes were not plotted for B. freija, since we so rarely recorded it there)

despite their small size. Within each bog type, abundance of some species also significantly differed among sites (Appendix 1); for muskegs (for which we have the largest sample of sites over the greatest geographical spread), these differences occurred both within and among subregions. The percentage of years we found the species covaried significantly with mean relative abundance for each species (Table 4). Nonetheless, at muskegs with longer survey routes (Armstrong, Glidden), we had a fairly reliable detection of presence each year (50-100\% of years surveyed) for species occurring in low abundance (B. freija at both sites, B. eunomia at Glidden) (Appendix 1), despite few visits (1-3) during the flight period per year.

Specialists with adequate formal sampling in nearby upland roadsides were significantly under-represented there (Fig. 3; Appendix 2). Flight period timing explained

Table 4 Coefficients $(r)$ and significance $(P)$ of Spearman rank correlations of proportion of years recorded as present in $N$ sites to mean abundance in each site as in "Appendix 1", by species

\begin{tabular}{llll}
\hline & $N$ & $r$ & $P$ \\
\hline Lycaena epixanthe & 27 & +0.760 & $<0.01$ \\
Boloria eunomia & 18 & +0.536 & $<0.05$ \\
Boloria freija & 15 & +0.849 & $<0.01$ \\
Oeneis jutta & 23 & +0.633 & $<0.01$ \\
\hline
\end{tabular}




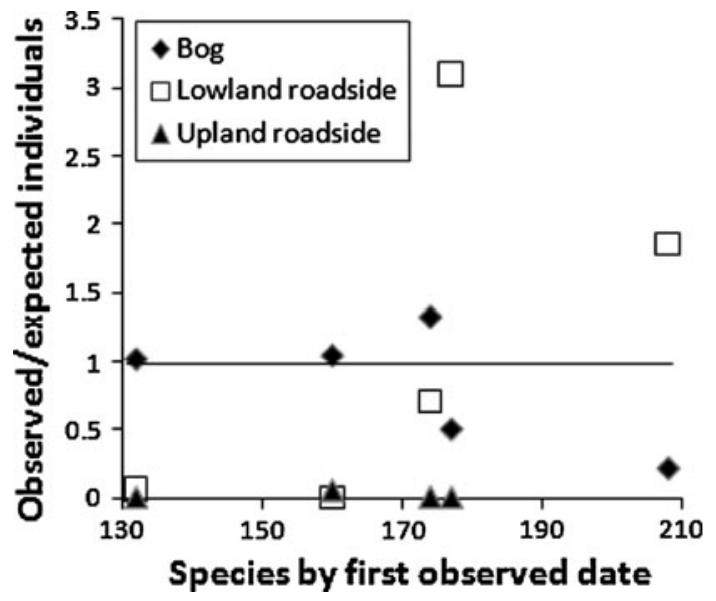

Fig. 3 Ratio of observed/expected individuals based on survey effort in bog, adjacent lowland roadside, and nearby upland roadside, by species (see "Appendix 2"), in order of first observed date (as in Table 2) expressed as sequentially numbered date. Random distribution $=1$ (observed $=$ expected $)$

whether bog specialists occurred in any numbers in adjacent lowland roadsides (Fig. 3; Appendix 2). Spring species were significantly under-represented there. Two summer species were significantly over-represented in these lowland roadsides compared to bogs, and the third (L. epixanthe) occurred in substantial numbers (Appendix 2), although still under-represented there. Bogs were relatively nectar-rich in spring, more so than the roadsides, but nectarpoor in summer, when the roadsides were nectar-rich.

L. epixanthe was remarkably detectable in cool, cloudy weather in coastal peatlands as well as inland kettleholes in the same county (Table 5). This was especially noticeable in the coastal peatlands due to the lower mean temperature and percent sunshine on surveys there. Some surveys in cool, cloudy weather produced "good" counts (Table 6), defined as abundances at least half the mean relative abundance of that site in "Appendix 1". This contrasted
Table 6 Surveys with low temperature $<24^{\circ} \mathrm{C}$ and $\leq 30 \%$ sunshine with Lycaena epixanthe observation rate half or more the mean observation rate on peak surveys in "Appendix 1", at sites (grouped by type, subregion, and county) analyzed in the table

\begin{tabular}{|c|c|c|c|c|}
\hline Site & Date & Temperature & $\begin{array}{l}\% \\
\text { Sunshine }\end{array}$ & $\begin{array}{l}\text { Obs } \\
\text { rate }\end{array}$ \\
\hline \multicolumn{5}{|c|}{ Coastal peatlands (Northwest: Bayfield coastal) } \\
\hline Bark Bay & $\begin{array}{l}27 \mathrm{Jul} \\
93\end{array}$ & 17 & $0 \%$ & 64.9 \\
\hline Bark Bay & $\begin{array}{l}24 \mathrm{Jul} \\
08\end{array}$ & 19 & 5 & 112.3 \\
\hline Bibon Lake & $\begin{array}{c}24 \mathrm{Jul} \\
08\end{array}$ & 22 & 2 & 96.9 \\
\hline $\begin{array}{l}\text { Port Wing Boreal } \\
\text { Forest }\end{array}$ & $\begin{array}{l}24 \mathrm{Jul} \\
08\end{array}$ & 19 & 30 & 228.0 \\
\hline Bibon Lake & $\begin{array}{c}23 \mathrm{Jul} \\
09\end{array}$ & 17 & 15 & 114.3 \\
\hline Bark Bay & $\begin{array}{l}7 \text { Aug } \\
09\end{array}$ & 22 & 20 & 109.4 \\
\hline \multicolumn{5}{|c|}{ Kettleholes (Northwest: Bayfield interior) } \\
\hline East Roger Lake & $9 \mathrm{Jul} 06$ & 20 & 1 & 240.0 \\
\hline Pine Lake & $\begin{array}{l}24 \mathrm{Jul} \\
08\end{array}$ & 22 & 0 & 525.0 \\
\hline East Wishbone Lake & $\begin{array}{c}24 \mathrm{Jul} \\
09\end{array}$ & 23 & 25 & 369.2 \\
\hline East Wishbone Lake & $\begin{array}{l}9 \text { Aug } \\
09\end{array}$ & 21 & 10 & 200.0 \\
\hline \multicolumn{5}{|c|}{ Muskeg (Central: Jackson) } \\
\hline Highway 54 & 4 Jul 09 & 20 & 0 & 213.9 \\
\hline
\end{tabular}

with inland surveys in Douglas County muskegs and adjacent lowland roadsides, which had the one significant weather effect (positive with percent sunshine) and no "good" counts in poor weather (Tables 5, 6). However, in 2009 in central Wisconsin (the hottest climate in this study), it was in poor weather that we obtained our highest count ever (82 individuals) of L. epixanthe there (Table 6).

Table 5 Spearman rank correlation coefficients $(r)$ (boldfaced if significant) of peak Lycaena epixanthe observation rates as analyzed in "Appendix 1" with low temperature and percent sunshine on each unit

survey, excluding sites (Lost Creek, East Crane Lake) significantly lower in abundance within that group of sites (see "Appendix 1")

\begin{tabular}{|c|c|c|c|c|}
\hline Bog site type & Coastal & Kettlehole & Muskeg & Muskeg lowland rdside \\
\hline County & Bayfield & Bayfield & Douglas & Douglas \\
\hline$N$ unit surveys & 24 & 24 & 45 & 41 \\
\hline Mean temperature $\left({ }^{\circ} \mathrm{C}\right)$ & 18.6 & 24.6 & 25.6 & 25.3 \\
\hline Range of temperature $\left({ }^{\circ} \mathrm{C}\right)$ & $17-32$ & $19-31$ & $17-32$ & $18-32$ \\
\hline Mean $\%$ sunshine $(\%)$ & 38.9 & 71.7 & 69.0 & 72.4 \\
\hline Range of $\%$ sunshine $(\%)$ & $0-100$ & $0-100$ & $0-100$ & $0-100$ \\
\hline \multicolumn{5}{|l|}{ Correlation $(r)$ with } \\
\hline Low temperature & -0.224 & -0.047 & +0.129 & -0.020 \\
\hline Percent sunshine & +0.255 & -0.363 & +0.359 & +0.282 \\
\hline
\end{tabular}




\section{Discussion}

\section{Cautions}

Frequent surveys under strict weather and timing protocols (e.g., Pollard 1977; Pollard and Yates 1993; Wikström et al. 2009) produce more robust results than our less frequent surveys in more variable weather and times of day. As a result, our abundance indices are more confounded by phenology and variation in detection due to weather. Therefore, the strongest findings in this study are relatively high abundances (despite these confounding factors), previously unreported presence of species in coastal peatlands and kettleholes, and results that are most consistent with others' independent findings, as discussed below.

\section{Characterization of bog butterfly fauna}

Nekola's (1998) report of L. epixanthe and B. eunomia as the dominant species in kettleholes, and the latter dominant in coastal peatlands, is consistent with the high abundances we recorded for both species in both bog types (Fig. 1) despite small bog sizes (Appendix 1). Agreeing with Nekola's (1998) report of significantly different peatland butterfly faunas among the three bog types, we found some significant differences in species' abundances among bog types (Appendix 1). Furthermore, we found significant differences in relative abundance within type among sites. Extraordinarily high abundances of a few species (L. epixanthe, B. eunomia) occurred in small kettleholes, consistent with a few reports of high numbers for L. epixanthe in the 4th of July butterfly counts (Opler and Powell 1984: 2000 individuals at Union City, Pennsylvania; Wander 2009: 1509 individuals at Central Franklin County, Massachusetts). High densities of B. aquilonaris have also been reported in European bogs (Baguette and Schtickzelle 2006). Furthermore, at two bogs of the same vegetative classification with similar host plant abundance, B. aquilonaris abundance varied six-fold in relation to sphagnum structure (carpet or hummock), which affected larval microclimate (Turlure et al. 2010). Small prairies can also have very high specialist numbers, e.g., 906 regal fritillaries (Speyeria idalia) in $1.25 \mathrm{~h}$ of surveying at an occasionally hayed 12 ha prairie on the Northern Loess Hills, Iowa count (Swengel and Opler 1996). Viable populations of localized butterfly have been reported for small British sites (Thomas 1984).

As Nekola (1998) noted, the North American literature indicated bog butterflies' preference for peatland margins, but that was generally not the case in his experience or ours. He noted an exception that B. montinus adults were primarily found at adjacent upland nectar, a description that includes flowers in the gravel edge of roads by lowland ditches adjacent to bogs. We found a few summer species, including that one, frequenting adjacent lowland roadsides but virtually none occurring in nearby upland roadsides (Fig. 3; Appendix 2). Furthermore, the use of adjacent lowland roadsides should be interpreted with caution. We sampled relatively few sites and they were biased toward opener, less brushy ditches with more of a wetland characteristic, which may exaggerate specialist use of roadsides. Some bogs, including small kettleholes and coastal peatlands, are entirely surrounded by formidable barriers (dense forest, Lake Superior). But others have places where they border more open vegetations, such as roadsides, grasslands, and marshes, so that it is not an obvious barrier (water, forest) that prevents specialist movement out of these bogs.

Movement vs. dispersal limitations

Nekola and Kraft (2002) reported significant clustering of both bog butterfly presences and absences. This may be attributable to metapopulation dynamics (both dispersal and dispersal limits). Although virtually undetected in this study (Table 2; Fig. 3; Appendix 2), some movement of specialists out of bogs and between them is still possible. As mapped in Nekola and Kraft (2002), many bogs occur in clusters with at least one other bog within $5 \mathrm{~km}$. This is within or near the maximum dispersal distance reported by Baguette and Schtickzelle (2006) for two bog specialists (13.5 km for B. aquilonaris and $4.6 \mathrm{~km}$ for B. eunomia) and within the effective colonization distance documented for other localized butterflies (e.g., Davies et al. 2005). However, in more fragmented landscapes, bog butterflies may be particularly disinclined to disperse out of a patch (Vandewoestijne and Baguette 2004, Schtickzelle et al. 2006), with maximum dispersal usually $<2 \mathrm{~km}$ (Mennechez et al. 2003). Many species of butterflies show variability in dispersal behavior among populations (Stevens et al. 2010), so that mobility observed in one context may not apply to another. Furthermore, examples of each bog type are mapped as $>10-15 \mathrm{~km}$ from the next nearest bog; e.g., Pine Lake (Appendix 1) is $>15 \mathrm{~km}$ from the next nearest bog, except for a few tiny patches much smaller than Pine Lake that we found. Thus, other factors besides metapopulation dispersal may contribute to this spatial patterning, such as subtle habitat quality factors and subdetectable numbers, leading to false negatives (a species may not be found every year in lower density sites; cf. Table 4; Appendix 1). Spatially correlated patterns today could also result from nondispersal and non-colonization following extirpation from local catastrophes (e.g., wildfire, protracted flood, extreme drought) that may have occurred a very long time ago. It would, however, be difficult to distinguish outlier colonization events from outlier retention events. 
Over geologic time, these bog-specialist butterflies had to move around the landscape because the bog vegetation they occupy now developed on topography under an ice sheet in the last glaciation (Curtis 1959, Wright 1983). By contrast, limits on their movement now are prominently apparent. Many bog specialists do not even frequent adjacent lowland roadside ditches, while all specialists seem to penetrate virtually no further than that (Tables 2; Fig. 3; Appendix 2). Bogs are scattered widely around northern Wisconsin but are $<1 \%$ of the landscape as a whole (Hoffman 2002), approximately as isolated as habitat patches in highly fragmented anthropogenic landscapes, such as tallgrass prairie (Samson and Knopf 1994). Layberry et al. (1998) report additional evidence for postglacial dispersal barriers. Tundra-adapted butterflies surviving the last Ice Age in the "Beringian Refugium" (Northern Yukon and areas westward) "dispersed northward and eastward with varying degrees of success": 32 tundra species in northern Yukon, only 11 as far east as northern Quebec. At the end of the last Ice Age, the vegetations occupied by these study species were likely not as disjunct then as they are now, given that most of these bog butterflies occupy a wider array of vegetation types in Canada now (Layberry et al. 1998). The exception is L. epixanthe, rather consistently restricted to bogs throughout its relatively more limited and more southerly range. More dispersal tendency may not have occurred then than now. Rather these butterflies may have occurred in more vegetation types in more of the landscape then, subsequently becoming more restricted to bogs, "high and dry" (or perhaps more appropriately, "sunk and dunked") as this vegetation became isolated patches.

Habitat quality vs. landscape configuration

Some kettleholes and coastal peatlands were relatively small and isolated (see map in Nekola and Kraft 2002) yet supported remarkably high densities of $L$. epixanthe and B. eunomia, as well as low but predictable numbers of O. jutta (Figs. 1, 2; Appendix 1), and occasionally even B. freija (Table 2). High habitat quality in the speciesspecific sense of consistently available required resources (as construed in Dennis and Eales 1997; Thomas et al. 2001; Dennis et al. 2007; Dennis 2010) appears more effective at explaining this than spatial reinforcement either from patch size or from the surrounding landscape. These dense populations of L. epixanthe and B. eunomia probably represent long-term population persistence in situ with little chance for immigration. However, some species occured only (e.g., E. discoidalis) or primarily (B. freija) in muskegs (Table 2; see "Results"), which were often larger (Appendix 1) and more connected in complexes (per map in Nekola and Kraft 2002), suggesting the value of large and connected habitat patches. Densities of some species were relatively high in some muskegs: e.g., $B$. freija (Fig. 2; Appendix 1), and cf. high numbers of B. montinus in the few bogs and adjacent lowland roadsides (Table 2; Fig. 3; Appendix 2) in the one county where found at all. However, while widely findable, bog specialists sometimes occurred only in small numbers: e.g., numerous sites with mean observation rates $<5 / \mathrm{h}$ in "Appendix 1 ", and these were the four most frequently recorded specialists (cf. Table 2). Pristine as these bogs are (a kind of high quality), the habitat can't be called all that good quality for those small populations-otherwise, they should be more abundant. Large size may be necessary to amass an adequate amount of required resources to sustain these populations (cf. Turlure et al. 2009, 2010), suggesting that habitat quality may be more important than it first seems in explaining the better occurrence of some specialists in bigger bogs.

\section{Co-evolution vs. stasis}

As Elias (1994) summarized, insects don't evolve out of trouble from climatic cycles; they move out of trouble. That is, remarkable stasis (species stability) is evident over millennia in the insect fossil record, but the location of these species has moved tremendously in association with vegetative changes responding to climatic oscillations (Ashworth 2001; Whitehouse 2006; Whitehouse et al. 2008). Given the low dispersal apparent today for species restricted to bogs (Spitzer et al. 1999; Spitzer and Danks 2006; see "Results"), "move" might be better understood as "hunkering" within their vegetation as it expands and shrinks and moves around the landscape. While evolution is often portrayed as an either-or choice ("adapt or die"discussed further below), it's actually a three-way possibility: "adapt or hold out or die". On the one hand, bog butterflies evidence ongoing evolutionary change. The "B. titania" species complex has a European taxon and in North America, a tundra taxon and a boreal taxon (B. montinus, the taxon studied here); many species or species complexes have tundra (sub)species and boreal (sub)species (Layberry et al. 1998). Local races or subspecies are evident among isolated bog regions for many bog insects (Wright 1983; Spitzer and Danks 2006). On the other hand, temperate bog butterflies appear not to have coevolved at all; they're hunkering in with the way of living they've been doing with remarkable long-term faunal stability, even though they can do this only in a very small part of the landscape $(<1 \%)$ in Wisconsin (per Hoffman 2002).

Even what might look like evolution may not be after all. L. epixanthe in coastal peatlands had seemed more detectable in poorer weather than in sites further inland 
(such as Douglas County muskegs) (Table 5), until we encountered the high density in central Wisconsin (Table 6) immediately after a drenching thunderstorm. This could instead be explained as pre-existing behavioral plasticity expressed differently in different circumstances. Likewise, dispersal tendency may evolve in response to varying degrees of habitat fragmentation (as described in Baguette et al. 2003; Hanski and Pöyry 2007) or the same pre-existing behavioral repertoire may instead be expressed differently depending on varying landscape circumstances as well as individual variation.

Some European butterflies have an affinity (even apparent modern-day restriction) to some forms of oldfashioned, unintensive agriculture and forest harvesting (van Swaay and Warren 2006). Although this apparent dependence may be attributed at least in part to co-evolution, this is often explained as butterflies expanding or contracting in these semi-natural landscapes based on the species' predispositions for these resources and conditions, without necessarily co-evolving (Erhardt and Thomas 1991; Dennis 1992; Dennis 2010). This latter is more consistent with the apparent lack of ongoing co-evolution occurring in the modern landscape (why would it stop a century or two ago?), and with the present-day "biodiversity crisis" most marked for more specialized species, but even affecting numerous widely occurring species (Maes and Van Dyck 2001; van Swaay et al. 2006; Dennis 2010).

Many assert co-evolution of prairie biota with fire (e.g., Curtis 1959; Wisconsin DNR 1995; Packard and Mutel 1997). Apart from controversy over just how much fire actually occurred prehistorically (cf. Higgins 1986; Umbanhowar 1996; Russell 1997), this assumes aboriginal inhabitants as a single culture applied fire in an inescapable and frequent way everywhere to become an unequivocal and unavoidable evolutionary pressure (forcing the outcome down to "adapt or die"). Even modern civilization hasn't fully and uniformly transformed the entire landscape, witness the continued existence of never-plowed botanically "high quality" prairie as well as temperatezone bogs in very small proportions of the landscape (see "Introduction"). If instead Native Americans varied among clans and tribes in activity and culture, with variable influence on the landscape (Russell 1997), including noman's zones between antagonistic tribes as reported in Martin and Szuter (1999), then butterflies could sort themselves out along such gradients as fire frequency and native herbivory pressure mediated by variable aboriginal hunting pressure. Some butterflies may have co-evolved in some form, but others may have successfully hunkered in, possibly in very small parts of the landscape, just as bog butterflies have reliably persisted in the $<1 \%$ of Wisconsin that is bog.
Whether it's co-evolution or not is less important when management proceeds based on conservation evidence for the species affected, as promulgated in Pullin and Knight (2001). But when conservation implements ecosystem management based on theoretical assumptions instead, then picking the right theory (e.g., co-evolution or stasis) becomes critical.

\section{Conclusions for conservation}

Dispersal, colonization, and landscape configuration matter (Dennis and Eales 1997; Thomas et al. 2001; Hanski and Pöyry 2007; Dover and Settele 2009; Dennis 2010). If metapopulation dynamics and/or the ecosystem approach are successfully conserving a particular site's insects (e.g., Davies et al. 2005), continue that. If not (e.g., specialist declines in relatively large preserves as in Schlicht et al. 2009), then it may be appropriate to imitate how nature maintains regionally appropriate numbers of highly localized bog butterflies in extremely fragmented patches via remarkable vegetative stability, as well as high habitat quality in the species-specific sense on small sites. Instead of relying on colonization, focus instead on retention because the otherwise inevitable long-term outcome for rare species is to have many more extirpations than colonizations (Bulman et al. 2007). This approach can be applied via detailed species-specific knowledge, but where that is lacking, the following multi-species/ecosystem approaches are indicated (in addition to vigorous effort to acquire species-specific knowledge). Be retrospective (not prospective) in continuing site stability (maintain consistency with past site management before investigating subtle, gradual approaches to restoration). Do not conflate vegetative variation among locations with change within a location (vegetative heterogeneity can be compatible with location-specific consistency).

Acknowledgments We greatly appreciate Mrs. Sandra McKibben and Drs. William and Elsa Boyce for funding our bog surveys. We also thank them, Jed Bromfield and Henya Rachmiel, U.S. Fish and Wildlife Service, and Wisconsin Department of Natural Resources for funding some barrens surveys. We thank Jeff Nekola for generously sharing tips, site locations, and patch sizes. Michel Baguette, an anonymous reviewer, and the editor John Dover provided numerous helpful comments on the submitted manuscript.

Open Access This article is distributed under the terms of the Creative Commons Attribution Noncommercial License which permits any noncommercial use, distribution, and reproduction in any medium, provided the original author(s) and source are credited.

\section{Appendix 1}

See Table 7. 
Table 7 Mean relative abundance (individuals/h) of four most abundant specialists on unit surveys of peak survey per site per year during 2002-2009, by groups of sites, sorted by bog type (with subregion and counties in parentheses)

\begin{tabular}{|c|c|c|c|c|c|}
\hline & Years & Mean & SD & Size & $\begin{array}{l}\text { Significance } \\
\text { within among }\end{array}$ \\
\hline \multicolumn{6}{|l|}{ Lycaena epixanthe } \\
\hline Kettleholes (Northwest: Bayfield interior) & & & & & A \\
\hline East Crane Lake & $4 / 4$ & 23.7 & 8.1 & 7.82 & $\mathrm{~B}$ \\
\hline East Roger Lake & $7 / 7$ & 222.3 & 194.9 & 1.84 & A \\
\hline East Wishbone Lake & $7 / 7$ & 335.5 & 181.2 & 4.12 & A \\
\hline Pine Lake & $4 / 4$ & 404.8 & 374.9 & 1.96 & $\mathrm{AB}$ \\
\hline Coastal Peatlands (Northwest: Bayfield coastal) & & & & & $\mathrm{B}$ \\
\hline Bark Bay & $8 / 8$ & 101.1 & 61.9 & 9.23 & A \\
\hline Bibon Lake & $7 / 7$ & 109.9 & 65.0 & 16.56 & A \\
\hline Lost Creek & $6 / 6$ & 28.5 & 19.7 & 2.93 & $\mathrm{~B}$ \\
\hline Port Wing Boreal Forest & $4 / 4$ & 204.3 & 142.6 & 2.40 & A \\
\hline Muskegs (Northwest: Douglas) & & & & & $\mathrm{C}$ \\
\hline Bear Lake & $6 / 7$ & 17.5 & 11.8 & $72.02^{\mathrm{a}}$ & A \\
\hline Bear Lake North & $4 / 6$ & 12.4 & 21.7 & $72.02^{\mathrm{a}}$ & $\mathrm{AB}$ \\
\hline Lyman Lake & $7 / 8$ & 9.8 & 17.4 & 50.55 & $\mathrm{~B}$ \\
\hline Milchesky Road & $7 / 8$ & 29.5 & 37.3 & 114.80 & $\mathrm{AB}$ \\
\hline Muskeg lowland roadsides (Northwest: Douglas) & & & & & $\mathrm{C}$ \\
\hline Bear Lake & $8 / 8$ & 35.3 & 50.6 & & A \\
\hline Bear Lake North & $6 / 8$ & 32.9 & 59.4 & & A \\
\hline Lyman Lake & $3 / 8$ & 4.1 & 6.0 & & A \\
\hline Milchesky Road & $3 / 8$ & 45.9 & 93.5 & & A \\
\hline Muskegs (North Central: Ashland, Iron, Price) & & & & & $\mathrm{C}$ \\
\hline Caroline Lake & $5 / 5$ & 28.7 & 29.7 & 52.58 & A \\
\hline Glidden & $8 / 8$ & 20.0 & 31.8 & 80.16 & A \\
\hline Highway 70/137 & $3 / 4$ & 5.8 & 5.3 & & A \\
\hline Muskeg lowland roadsides (North Central: Ashland, Iron) & & & & & $\mathrm{C}$ \\
\hline Caroline Lake & $1 / 4$ & 2.7 & 5.5 & & A \\
\hline Caroline Lake east 0.2 & $0 / 3$ & 0.0 & 0.0 & & - \\
\hline Caroline Lake east 1.0 & $0 / 3$ & 0.0 & 0.0 & & - \\
\hline Glidden & $6 / 8$ & 20.7 & 31.8 & & A \\
\hline Muskegs (Northeast: Forest) & & & & & $\mathrm{C}$ \\
\hline Armstrong & $8 / 8$ & 20.1 & 31.8 & & A \\
\hline Forest Road 2182 West & $4 / 6$ & 14.2 & 16.7 & & A \\
\hline Forest Road 2182/2414 & $4 / 7$ & 5.0 & 6.3 & & A \\
\hline Forest Road 2414 & $4 / 7$ & 4.6 & 5.7 & & A \\
\hline \multicolumn{6}{|l|}{ Boloria eunomia } \\
\hline Kettleholes (Northwest: Bayfield interior) & & & & & A \\
\hline East Crane Lake & $4 / 6$ & 36.7 & 57.6 & 7.82 & A \\
\hline East Roger Lake & $6 / 6$ & 85.5 & 66.1 & 1.84 & A \\
\hline East Wishbone Lake & $6 / 6$ & 48.4 & 56.6 & 4.12 & A \\
\hline Pine Lake & $5 / 6$ & 22.6 & 16.5 & 1.96 & A \\
\hline Coastal Peatlands (Northwest: Bayfield coastal) & & & & & A \\
\hline Bark Bay & $7 / 7$ & 43.0 & 39.5 & 9.23 & $\mathrm{BC}$ \\
\hline Bibon Lake & $7 / 7$ & 59.6 & 39.8 & 16.56 & $\mathrm{AB}$ \\
\hline Lost Creek & $6 / 7$ & 24.0 & 17.4 & 2.93 & $\mathrm{C}$ \\
\hline Port Wing Boreal Forest & $7 / 7$ & 144.0 & 124.5 & 2.40 & A \\
\hline
\end{tabular}


Table 7 continued

\begin{tabular}{|c|c|c|c|c|c|}
\hline & Years & Mean & $\mathrm{SD}$ & Size & $\begin{array}{l}\text { Significance } \\
\text { within among }\end{array}$ \\
\hline Muskegs (Northwest: Douglas) & & & & & $\mathrm{B}$ \\
\hline Bear Lake & $7 / 7$ & 5.2 & 6.4 & $72.02^{\mathrm{a}}$ & A \\
\hline Bear Lake North & $6 / 7$ & 8.2 & 9.3 & $72.02^{\mathrm{a}}$ & A \\
\hline Lyman Lake & $5 / 8$ & 2.8 & 4.4 & 50.55 & A \\
\hline Milchesky Road & $5 / 7$ & 4.6 & 5.0 & 114.80 & A \\
\hline Muskegs (North Central: Ashland, Price, Washburn) & & & & & $\mathrm{B}$ \\
\hline Glidden & $8 / 8$ & 1.8 & 4.8 & 80.16 & $\mathrm{C}$ \\
\hline Highway 77 & $5 / 6$ & 5.9 & 4.7 & & $\mathrm{AB}$ \\
\hline Forest Road 1371.9 & $2 / 5$ & 1.2 & 2.9 & & $\mathrm{C}$ \\
\hline Forest Road 1372.3 & $2 / 5$ & 2.3 & 3.3 & & $\mathrm{BC}$ \\
\hline Highway 70/137 & $4 / 4$ & 15.8 & 8.9 & & A \\
\hline Muskegs (Northeast: Forest) & & & & & $\mathrm{B}$ \\
\hline Armstrong & $6 / 6$ & 5.7 & 10.8 & - & \\
\hline \multicolumn{6}{|l|}{ Boloria freija } \\
\hline Muskegs (Northwest: Douglas) & & & & & A \\
\hline Bear Lake & $8 / 8$ & 31.0 & 14.7 & $72.02^{\mathrm{a}}$ & A \\
\hline Bear Lake North & $7 / 7$ & 25.9 & 15.3 & $72.02^{\mathrm{a}}$ & A \\
\hline Lyman Lake & $8 / 8$ & 17.8 & 17.5 & 50.55 & A \\
\hline Milchesky Road & $8 / 8$ & 16.7 & 13.6 & 114.80 & A \\
\hline Muskegs (North Central: Ashland, Iron, Price) & & & & & $\mathrm{B}$ \\
\hline Caroline Lake & $5 / 5$ & 16.5 & 13.3 & 52.58 & A \\
\hline Glidden & $4 / 7$ & 0.9 & 2.6 & 80.16 & $\mathrm{CD}$ \\
\hline Forest Road 1371.2 & $4 / 8$ & 2.8 & 5.0 & & $\mathrm{C}$ \\
\hline Forest Road 1371.9 & $7 / 8$ & 6.4 & 7.6 & & $\mathrm{AB}$ \\
\hline Forest Road 1372.3 & $6 / 8$ & 6.2 & 9.8 & & $\mathrm{AB}$ \\
\hline Forest Road 5051.6 & $7 / 7$ & 4.0 & 6.4 & & $\mathrm{BC}$ \\
\hline Muskegs (Northeast: Forest) & & & & & $\mathrm{C}$ \\
\hline Forest Road 21820.5 & $7 / 8$ & 8.4 & 7.0 & & A \\
\hline Forest Road 21821.4 & $1 / 8$ & 1.0 & 2.9 & & $\mathrm{~B}$ \\
\hline Forest Road 2182/2414 & $2 / 7$ & 0.9 & 1.6 & & $\mathrm{~B}$ \\
\hline Forest Road 2414 & $2 / 8$ & 0.8 & 1.5 & & $\mathrm{~B}$ \\
\hline Armstrong & $4 / 8$ & 0.6 & 2.5 & & $\mathrm{~B}$ \\
\hline \multicolumn{6}{|l|}{ Oeneis jutta } \\
\hline Kettleholes (Northwest: Bayfield interior) & & & & & $\mathrm{CD}$ \\
\hline East Roger Lake & $1 / 5$ & 0.7 & 1.6 & 1.84 & $\mathrm{AB}$ \\
\hline East Wishbone Lake & $1 / 6$ & 0.6 & 1.5 & 4.12 & $\mathrm{~B}$ \\
\hline East Crane Lake & $4 / 5$ & 4.6 & 4.4 & 7.82 & A \\
\hline Pine Lake & $0 / 4$ & 0.0 & 0.0 & 1.96 & $\mathrm{AB}$ \\
\hline Coastal Peatlands (Northwest: Bayfield coastal) & & & & & $\mathrm{D}$ \\
\hline Bark Bay & $0 / 6$ & 0.0 & 0.0 & 9.23 & $\mathrm{~B}$ \\
\hline Bibon Lake & $5 / 7$ & 3.6 & 2.6 & 2.40 & A \\
\hline Lost Creek & $0 / 5$ & 0.0 & 0.0 & 2.93 & $\mathrm{AB}$ \\
\hline Port Wing Boreal Forest & $0 / 6$ & 0.0 & 0.0 & 16.56 & $\mathrm{~B}$ \\
\hline Muskegs (Northwest: Douglas) & & & & & $\mathrm{B}$ \\
\hline Bear Lake & $8 / 8$ & 11.2 & 15.5 & $72.02^{\mathrm{a}}$ & $\mathrm{AB}$ \\
\hline Bear Lake North & $8 / 8$ & 19.3 & 12.8 & $72.02^{\mathrm{a}}$ & A \\
\hline Lyman Lake & $8 / 8$ & 11.3 & 12.2 & 50.55 & $\mathrm{~B}$ \\
\hline Milchesky Road & $5 / 7$ & 7.9 & 6.9 & 114.80 & $\mathrm{~B}$ \\
\hline
\end{tabular}


Table 7 continued

\begin{tabular}{|c|c|c|c|c|c|}
\hline & Years & Mean & SD & Size & $\begin{array}{l}\text { Significance } \\
\text { within among }\end{array}$ \\
\hline Muskegs (North Central: Ashland, Iron, Price, Washburn) & & & & & $\mathrm{AC}$ \\
\hline Glidden & $7 / 8$ & 6.0 & 10.9 & 80.16 & A \\
\hline Highway 77 & $5 / 7$ & 7.4 & 6.4 & & A \\
\hline Forest Road 1371.9 & $6 / 8$ & 10.1 & 15.9 & & A \\
\hline Forest Road 1372.3 & $6 / 7$ & 4.6 & 7.3 & & A \\
\hline Highway 70/137 & $1 / 4$ & 1.2 & 2.4 & & A \\
\hline Caroline Lake & $4 / 5$ & 6.0 & 6.0 & 52.58 & A \\
\hline Muskegs (Northeast: Forest) & & & & & A \\
\hline Forest Road 21820.5 & $4 / 8$ & 14.4 & 18.5 & & $\mathrm{AB}$ \\
\hline Forest Road 21821.4 & $5 / 7$ & 32.3 & 31.7 & & A \\
\hline Armstrong & $6 / 7$ & 10.2 & 22.7 & & $\mathrm{~B}$ \\
\hline Forest Road 2182/2414 & $5 / 7$ & 17.9 & 16.0 & & $\mathrm{AB}$ \\
\hline Forest Road 2414 & $5 / 7$ & 28.5 & 31.3 & & $\mathrm{AB}$ \\
\hline
\end{tabular}

"Yrs" $=N$ years found $/ N$ years surveyed. Patch size (ha) provided by J. Nekola (personal communication), except we estimated patch size for Port Wing Boreal Forest. For each species, within each group of sites, sites sharing no letters are significantly different, and among groups, groups sharing no letters are significantly different: A, significantly highest; B, significantly lower than A; C, significantly lower than B, and so on

a Treated as one site by J. Nekola (personal communication)

\section{Appendix 2}

See Table 8 .

Table 8 Distribution of specialist individuals in bog, adjacent lowland roadsides, and nearby upland roadsides during the entire study, in order of first observed date in Table 2

\begin{tabular}{|c|c|c|c|}
\hline & Bog & Lowland roadside & Upland roadside \\
\hline \multicolumn{4}{|l|}{ B. freija } \\
\hline Observed & 722 & 0 & 0 \\
\hline Survey time & 100.0 & & \\
\hline \multicolumn{4}{|l|}{ E. discoidalis } \\
\hline Observed & 128 & 1 & 0 \\
\hline Survey time & 71.7 & & \\
\hline \multicolumn{4}{|l|}{ Oeneis jutta } \\
\hline Observed & $962(\mathbf{9 9 . 9 \%})$ & $1(0.1 \%)$ & $0 \underline{(0.0 \%)}$ \\
\hline Expected & $940.9(97.7 \%)$ & $14.9(1.6 \%)$ & $7.1(0.7 \%)$ \\
\hline Survey time & 159.6 & 2.5 & 1.2 \\
\hline \multicolumn{4}{|l|}{ B. frigga } \\
\hline Observed & 264 & $0(1)$ & 0 \\
\hline Survey time & 107.9 & & \\
\hline \multicolumn{4}{|l|}{ B. eunomia } \\
\hline Observed & $1084(\mathbf{9 9 . 9 \%})$ & $0 \underline{(0.0 \%)}$ & 1 (1) $(0.1 \%)$ \\
\hline Expected & $1035.3(95.4 \%)$ & $30.6(2.8 \%)$ & $19.1(1.8 \%)$ \\
\hline Survey time & 82.4 & 2.4 & 1.5 \\
\hline \multicolumn{4}{|l|}{ L. epixanthe } \\
\hline Observed & $3986(\mathbf{8 5 . 5 \%})$ & $674(14.5 \%)$ & $2 \underline{(0.0 \%)}$ \\
\hline Expected & $2995.7(64.3 \%)$ & $946.0(20.3 \%)$ & $720.2(15.4 \%)$ \\
\hline Survey time & 91.7 & 29.0 & 22.0 \\
\hline
\end{tabular}

Table 8 continued

\begin{tabular}{llll}
\hline & Bog & Lowland roadside & Upland roadside \\
\hline L. dorcas & & & \\
Observed & $161(29.4 \%)$ & $386(\mathbf{7 0 . 6 \%})$ & $0 \underline{(0.0 \%)}$ \\
Expected & $319.7(58.5 \%)$ & $124.5(22.8 \%)$ & $102.8(18.8 \%)$ \\
Survey time & 61.0 & 23.8 & 19.6 \\
B. montinus & & & \\
Observed & $192 \underline{(11.1 \%)}$ & $1538(\mathbf{8 8 . 9 \%})$ & $(0)$ \\
Expected & $898.7(52.0 \%)$ & $831.3(48.0 \%)$ & \\
Survey time & 23.4 & 21.6 & \\
\hline
\end{tabular}

Observed individuals for each species are significantly skewed relative to expected based on proportion of survey time (h) in each site type (chi square goodness of fit $P=0.0000$ for each species). Most over-represented is boldfaced; most under-represented is underlined. If roadside survey time was $<1 \mathrm{~h}$, that site type was excluded from statistical analysis but $N$ individuals observed on those surveys is provided. $N$ individuals on informal observations is in parentheses but excluded from analysis

\section{References}

Ashworth AC (2001) Chapter 8: Perspectives on quaternary beetles and climate change. In Gerhard LC, Harrison WE, Hanson BM (eds) Geological perspectives of global climate change. American Association of Petroleum Geologists Studies in Geology \#47, Tulsa, pp 153-168

Baguette M, Schtickzelle N (2006) Negative relationship between dispersal distance and demography in butterfly metapopulations. Ecology 87:648-654 
Baguette M, Mennechez G, Petit S, Schtickzelle N (2003) Effect of habitat fragmentation on dispersal in the butterfly Proclossiana eunomia. C R Biol 326:S200-S209

Brown KS (1997) Diversity, disturbance, and sustainable use of neotropical forests: insects as indicators for conservation monitoring. J Insect Conserv 1:25-42

Bulman CR, Wilson RJ, Holt AR, Galvez Brávo L, Early RI, Warren MS, Thomas CD (2007) Minimum viable metapopulation size, extinction debt, and the conservation of declining species. Ecol Appl 17:1460-1473

Cassie B, Glassberg J, Swengel A, Tudor G (2001) North American Butterfly Association (NABA) checklist \& English names of North American butterflies, 2nd edn. N. Am. Butterfly Assoc, Morristown

Curtis JT (1959) The vegetation of Wisconsin: an ordination of plant communities. Univ of Wisconsin Press, Madison

Davies ZG, Wilson RJ, Brereton TM, Thomas CD (2005) The reexpansion and improving status of the silver-spotted skipper butterfly (Hesperia comma) in Britain: a metapopulation success story. Biol Conserv 124:189-198

Dennis RLH (1992) The ecology of butterflies in Britain. Oxford Univ Press, Oxford

Dennis RLH (2010) A resource-based habitat view for conservation: butterflies in the British landscape. Wiley-Blackwell, Oxford

Dennis RLH, Eales HT (1997) Patch occupancy in Coenonympha tullia (Müller, 1764) (Lepidoptera: Satyrinae): habitat quality matters as much as patch size and isolation. J Insect Conserv $1: 167-176$

Dennis RLH, Hardy PB (2007) Support for mending the matrix: resource seeking by butterflies in apparent non-resource zones. J Insect Conserv 11:157-168

Dennis RLH, Shreeve TG, Sheppard DA (2007) Species conservation and landscape management: a habitat perspective. In: Stewart AJA, New TR, Lewis OT (eds) Insect conservation biology: proceedings of the Royal Entomological Society's 23rd symposium. CABI, Oxfordshire, pp 92-126

Dover J, Settele J (2009) The influences of landscape structure on butterfly distribution and movement: a review. J Insect Conserv 13:3-28. doi:10.1007/s10841-008-9135-8

Elias SA (1994) Quaternary insects and their environments. Smithsonian Institution, Washington

Erhardt A, Thomas JA (1991) Lepidoptera as indicators of change in the semi-natural grasslands of lowland and upland Europe. In: Collins NM, Thomas JA (eds) The conservation of insects and their habitats. Academic Press, London, pp 213-236

Forister ML, McCall AC, Sanders NJ et al (2010) Compounded effects of climate change and habitat shift patterns of butterfly diversity. Proc Nat Acad Sci (Philadelphia) 107:2088-2092

Glassberg J (1999) Butterflies through binoculars: the East. Oxford Univ Press, New York

Hanski I, Pöyry J (2007) Insect populations in fragmented habitats. In: Stewart AJA, New TR, Lewis OT (eds) Insect conservation biology: proceedings of the Royal Entomological Society's 23rd Symposium. CABI, Oxfordshire, pp 175-202

Higgins KF (1986) Interpretation and compendium of historical fire accounts in the northern Great Plains. US Fish and Wildlife Service Resource Publication 151, Washington

Hoffman RM (2002) Wisconsin's natural communities: how to recognize them, where to find them. Univ of Wisconsin Press, Madison

Layberry RA, Hall PW, LaFontaine JD (1998) The butterflies of Canada. Univ of Toronto Press, Toronto

Maes D, Van Dyck H (2001) Butterfly diversity loss in Flanders (north Belgium): Europe's worst case scenario? Biol Conserv 99:263-276
Martin PS, Szuter CR (1999) War zones and game sinks in Lewis \& Clark's West. Conserv Biol 13:36-45

Mattoni R, Longcore T, Zonneveld C, Novotny V (2001) Analysis of transect counts to monitor population size in endangered insects: the case of the El Segundo blue butterfly (Euphilotes bernardino allyni). J Insect Conserv 5:197-206. doi:10.1023/A:10179879 29824

Mennechez G, Schtickzelle N, Baguette M (2003) Metapopulation dynamics of the bog fritillary butterfly: comparison of demographic parameters and dispersal between a continuous and a highly fragmented landscape. Landsc Ecol 18:279-291

Nekola JC (1998) Butterfly (Lepidoptera: Lycaenidae, Nymphalidae, and Satyridae) faunas of three peatland habitat types in the Lake Superior drainage basin of Wisconsin. Great Lakes Entomol 31:27-38

Nekola JC, Kraft CE (2002) Spatial constraint of peatland butterfly occurrences within a heterogeneous landscape. Oecologia 130:53-61

Nielsen M (1999) Michigan butterflies and skippers. Michigan State Univ Extension, East Lansing

Nuzzo VA (1986) Extent and status of Midwest oak savanna: presettlement and 1985. Nat Areas J 6:6-36

Opler PA (1992) A field guide to eastern butterflies. Houghton Mifflin, New York

Opler PA, Krizek GO (1984) Butterflies east of the great plains. Johns Hopkins Univ Press, Baltimore

Opler PA, Powell JA (eds) (1984) Butterfly counts 1982 \& 1983. Xerces Society, New Haven

Packard S, Mutel CF (1997) The tallgrass restoration handbook: for prairies, savannas and woodlands. Island Press, Washington

Pollard E (1977) A method for assessing changes in abundance of butterflies. Biol Conserv 12:115-133

Pollard E, Yates TJ (1993) Monitoring butterflies for ecology and conservation. Chapman \& Hall, London

Pullin AS, Knight TM (2001) Effectiveness in conservation practice: pointers from public health and medicine. Conserv Biol 15:50-54

Riegler M (1995) Development of a pine barrens recovery plan. In: Borgerding, EA, Bartelt GA, McCown MA (eds) The future of pine barrens in northwest Wisconsin: a workshop summary. Wisconsin Dept Nat Res PUBL-RS-913-94, pp 28-33

Russell EWB (1997) People and the land through time: linking ecology and history. Yale Univ Press, New Haven

Samson F, Knopf F (1994) Prairie conservation in North America. Bioscience 44:418-421

Schlicht D, Swengel A, Swengel S (2009) Meta-analysis of survey data to assess trends of prairie butterflies in Minnesota, USA during 1979-2005. J Insect Conserv 13:429-447

Schtickzelle N, Mennechez G, Baguette M (2006) Dispersal depression with habitat fragmentation in the bog fritillary butterfly. Ecology 87:1057-1065

Spencer S, Collins S (2008) Reversing the decline in butterflies and moths across Europe-the importance of particular farming practices and the implications for CAP reform. www.birdlife.eu/ eu/pdfs/BCEurope_CAPreformpaperFeb08.pdf viewed 15 Jan 2010

Spitzer K, Danks HV (2006) Insect biodiversity of boreal peat bogs. Annu Rev Entomol 51:137-161

Spitzer K, Bezdĕk A, Jaroš J (1999) Ecological succession of a relict Central European peat bog and variability of its insect biodiversity. J Insect Conserv 3:97-106

Stevens VM, Pavoine S, Baguette M (2010) Variation within and between closely related species uncovers high intra-specific variability in dispersal. PLoS ONE 5(6):e11123. doi:10.1371/ journal.pone.0011123 
Swengel AB (1996) Effects of fire and hay management on abundance of prairie butterflies. Biol Conserv 76:73-85

Swengel AB (1998) Effects of management on butterfly abundance in tallgrass prairie and pine barrens. Biol Conserv 83:77-89

Swengel A (2009) The fascinating butterflies of northwestern Wisconsin bogs. Southern Wisconsin Butterfly Assocation, Madison, Wisconsin. http://www.naba.org/chapters/nabawba/ watching.html viewed 11 Feb 2010

Swengel AB, Opler PA (1996) NABA-Xerces Fourth of July Butterfly Counts 1995 Report. North American Butterfly Association, Morristown

Swengel AB, Swengel SR (1997) Co-occurrence of prairie and barrens butterflies: applications to ecosystem conservation. J Insect Conserv 1:131-144

Swengel A, Swengel S (1999a) Observations on prairie skippers (Oarisma poweshiek, Hesperia dacotae, H. ottoe, H. leonardus pawnee, and Atrytone arogos iowa) (Lepidoptera: Hesperiidae) in Iowa, Minnesota, and North Dakota during 1988-1997. Great Lakes Entomol 32:267-292

Swengel SR, Swengel AB (1999b) Correlations in abundance of grassland songbirds and prairie butterflies. Biol Conserv 90:1-11

Swengel AB, Swengel SR (2001) Effects of prairie and barrens management on butterfly faunal compostion. Biodivers Conserv 10:1757-1785

Swengel AB, Swengel SR (2005) Long-term population monitoring of the Karner Blue (Lepidoptera: Lycaenidae) in Wisconsin, 1990-2004. Great Lakes Entomol 38:107-134

Swengel AB, Swengel SR (2007) Benefit of permanent non-fire refugia for Lepidoptera conservation in fire managed sites. J Insect Conserv 11:263-279

Thomas JA (1984) The conservation of butterflies in temperate countries: past efforts and lessons for the future. In: Vane-Wright RI, Ackery PR (eds) The biology of butterflies. Princeton Univ Press, Princeton, pp 333-353

Thomas JA, Bourn NAD, Clarke RT et al (2001) The quality and isolation of habitat patches both determine where butterflies persist in fragmented landscapes. Proc $\mathrm{R}$ Soc Lond $\mathrm{B}$ 268:1791-1796
Turlure C, Van Dyck H, Schtickzelle N, Baguette M (2009) Resourcebased habitat definition, niche overlap and conservation of two sympatric glacial relict butterflies. Oikos 118:950-960

Turlure C, Choutt J, Baguette M, Van Dyck H (2010) Microclimatic buffering and resource-based habitat in a glacial relict butterfly: significance for conservation under climate change. Glob Change Biol 16:1883-1893

Umbanhowar CE Jr (1996) Recent fire history of the northern Great Plains. Am Midl Nat 135:115-121

Väisänen R (1992) Distribution and abundance of diurnal Lepidoptera on a raised bog in southern Finland. Ann Zool Fennici 29:75-92

van Swaay CAM, Warren MS, Loïs G (2006) Biotope use and trends of European butterflies. J Insect Conserv 10:189-209

van Swaay CAM, Warren MS (2006) Prime butterfly areas of Europe: an initial selection of priority sites for conservation. J Insect Conserv 10:5-11

Vandewoestijne S, Baguette M (2004) Genetic population structure of the vulnerable bog fritillary butterfly. Hereditas 141:199-206

Wander S (ed) (2009) NABA butterfly counts (2008). North American Butterfly Assoc, Morristown

Whitehouse NJ (2006) What can forest managers learn from research on fossil insects? Linking forest ecological history, biodiversity and management. In: Grove SJ, Janula JL (eds) Insect biodiversity and dead wood: proceedings of a symposium for the 22nd international congress of entomology. Gen. Tech. Rep. SRS-93. USDA Forest Service, Southern Research Station, Asheville, pp 30-41

Whitehouse NJ, Langdon PG, Bustin R, Galsworthy S (2008) Fossil insects and ecosystem dynamics in wetlands: implications for biodiversity and conservation. Biodivers Conserv 17:2055-2078

Wikström L, Milberg P, Bergman K-O (2009) Monitoring of butterflies in semi-natural grasslands: diurnal variation and weather effects. J Insect Conserv 13:203-211

Wisconsin Department of Natural Resources (1995) Wisconsin's biodiversity as a management issue. Dept of Nat Res, Madison

Wright DM (1983) Life history and morphology of the immature stages of the bog copper butterfly Lycaena epixanthe (Bsd. \& Le C.) (Lepidoptera: Lycaenidae). J Res Lepid 22:47-100 